Brit. F. vener. Dis. (1968), 44, 254.

\title{
CARCINOMA OF THE CERVIX AMONG PROSTITUTES IN A WOMEN'S PRISON*
}

\author{
BY
}

\author{
ELIZABETH KEIGHLEY \\ Royal Northern Hospital, London
}

This paper reports the results of an investigation into the occurrence of carcinoma of the cervix among a group of prostitutes confined in a large women's prison. The Special Clinic of the prison acts as a diagnostic clinic and since a majority of the prisoners attend there to undergo routine genital examination for the detection of venereal and other genital diseases, it seemed an appropriate place in which to carry out cervical cytology tests. It was decided that from January, 1966, onwards cervical smears should be taken from as many women aged 25 years or over as was possible and that any younger girl who asked for a "smear test" should also be examined as it was considered that her interest should be encouraged. 844 women underwent this examination, 55 of them being under the age of 25 years at the time the test was taken. It soon became apparent that the majority of positive results were found in specimens taken from women who admitted to prostitution and at the end of the year of survey the number of prostitutes tested amounted to 190 .

Valid test results were obtained from 185 of these 190 women. The discrepancy of five arose because in fifteen cases the smear appearances were confused by the presence of acute infestation with $T$. vaginalis; in ten of these cases satisfactory smears were obtained after cure of the infestation and the result was positive in one, but the other five patients had been released from prison before a satisfactory repeat smear could be obtained. In all, positive test results were obtained from nineteen of the 185 women. The age distributions of all the prostitutes examined and of those whose tests yielded positive results are shown in Table I. No positive or doubtful test results were obtained from the sixteen girls who were under the age of 25 years.

Some difficulty was experienced with the next stage of the investigation, cone biopsy. Ten of the nineteen women had already been released before the results of the cervical cytology tests had been returned, but fortunately four of them were again

\footnotetext{
* Received for publication July 18, 1967.
}

TABLE I

RESULTS IN 190 PROSTITUTES EXAMINED BY CERVICAL CYTOLOGY TESTS

\begin{tabular}{l|c|c|c}
\hline $\begin{array}{c}\text { Age Group } \\
\text { (yrs) }\end{array}$ & $\begin{array}{c}\text { Number of } \\
\text { Women }\end{array}$ & $\begin{array}{c}\text { Valid } \\
\text { Smears }\end{array}$ & $\begin{array}{c}\text { Number of } \\
\text { Positive } \\
\text { Smears }\end{array}$ \\
\cline { 1 - 3 } $19-24$ & 16 & 16 & Nil \\
$25-30$ & 73 & 69 & 7 \\
$31-35$ & 26 & 25 & 4 \\
$36-40$ & 19 & 19 & 3 \\
$41-50$ & 34 & 34 & 2 \\
$51-60$ & 20 & 20 & 3 \\
61 and Over & 2 & 2 & Nil \\
\hline \multicolumn{1}{c|}{ Total } & 190 & 185 & 19 \\
\hline
\end{tabular}

sentenced to the same prison later in the year and could be admitted to the neighbouring Royal Northern Hospital during this second period of imprisonment. Three women underwent their cone biopsies in hospitals elsewhere in London. No difficulty was experienced with nine women who remained in prison; the gynaecologists at the Royal Northern Hospital were most co-operative and admitted these women as priority cases. Of the three women who have not yet undergone cone biopsy, one could not be traced and two were pregnant.

The positive cytology test results in the cases of the sixteen women who underwent cone biopsy were all confirmed; no case of invasive carcinoma was found but in two it was reported that "invasion appeared to be imminent". One of these patients was aged 32 and the other 52 years. Twelve of the sixteen women have already undergone hysterectomy, two are awaiting this operation, and two are being kept under surveillance because the carcinoma-in-situ appeared to have been removed satisfactorily by the cone biopsy procedure. Table II shows the actual ages of the prostitutes with positive results to cervical cytology tests, those with biopsy proved carcinoma-in-situ being indicated by an asterisk. 
TABLE II

AGES OF PROSTITUTES WITH POSITIVE CERVICAL SMEARS

\begin{tabular}{c|c|c|c|c|c}
\hline Age Group & $25-30$ & $31-35$ & $36-40$ & $41-50$ & $51-60$ \\
\hline $\begin{array}{c}\text { Individual } \\
\text { Ages } \\
\text { yrs) }\end{array}$ & 25 & 32 & $36^{*}$ & $44^{*}$ & $52^{*}$ \\
& $26^{*}$ & $32^{*}$ & $37^{*}$ & $49^{*}$ & $53^{*}$ \\
$27^{*}$ & $33^{*}$ & $38^{*}$ & & $55^{*}$ \\
& $28^{*}$ & $35^{*}$ & & & \\
& $28^{*}$ & & & & \\
& $29 *$ & & & & \\
\hline Group Totals & 30 & & & & \\
\hline
\end{tabular}

Thus this investigation has shown that there was presumptive evidence of carcinoma of the cervix in nineteen out of 185 prostitutes, an incidence of $10 \cdot 3$ per cent., and proof by biopsy has so far been obtainable in sixteen of 185 cases, an incidence of $8 \cdot 6$ per cent. Clearly one of the most serious occupational hazards to women who have lived a life of prostitution is the risk of developing carcinoma of the cervix. In a prison news travels fast and the women who have been found to have cancer have talked freely with the result that many prostitutes are now asking for their "cancer test" as soon as they enter the clinic; several have stated that they understood cancer to be more common in prostitutes. If such women can be trained to undergo regular examination by cervical cytology tests something important has been accomplished.

\section{Summary}

During the year 1966, cervical cytology tests were performed on 190 prostitutes confined in a women's prison in London. Valid test results were obtained in 185 cases, of which nineteen were positive ( 10.3 per cent.). Confirmation of the diagnosis of carcinoma-in-situ by cone biopsy has so far been obtained in sixteen cases, an incidence of 8.6 per cent. of the 185 women examined. No case of invasive carcinoma was recognized. The youngest prostitute with proven carcinoma was aged 25 . No positive or doubtful results to cervical cytology tests were found in the sixteen cases of girls under the age of 25 years. The possibility of developing carcinoma of the cervix appears to be one of the major hazards to which girls adopting a life of prostitution are exposed.

My grateful thanks are due to Dr Michael Peters, consultant pathologist to the Royal Northern Hospital, and to the consultant gynaecologists to the Royal Northern Hospital, Mr Mitchell Rees, Mr Elliot Philipp, and Mr Ian Donaldson.

\section{Le cancer du col parmi les prostituées dans une prison de femmes}

RÉSUMÉ

Pendant l'année 1966 dès tests cytologiques cervicaux ont été faits sur 190 prostituées dans une prison de femmes à Londres. Des résultats sûrs ont été obtenus dans 185 cas, et de ces cas 19 étaient positifs (10,3 pour cent). La confirmation du diagnostic du cancer in-situ par une biopsie conique a été obtenue jusqu'ici chez 16 cas, une incidence de 8,6 pour cent des 185 femmes examinées. Aucun cas de cancer diffus n'a été reconnu. La plus jeune des prostituées atteint de cancer reconnu était agée de 25 ans. Aucun résultat positif ou douteux après des tests cytologiques cervicaux n'avait été obtenu chez les 16 cas de filles agées de moins de 25 ans. La possibilité de développer le cancer du col semble être un des risques importants auxquels les filles qui s'adonnent à la prostitution sont exposées. 